\title{
Regulation of CD4+CD25+FOXP3+ Treg Cells in Systemic Lupus Erythematosus (SLE): Association With miRNAs Expression
}

\author{
Abeer M. El-Maghraby \\ University of Sadat City \\ Yasser B.M. Ali \\ University of Sadat City \\ Eman El-maadawy \\ University of Sadat City \\ Mohamed F. Elshal \\ University of Sadat City \\ Iman H Bassyouni \\ Cairo University Kasr Alainy Faculty of Medicine \\ Islam M El-Garawani \\ Menoufia University \\ roba talaat ( $\nabla$ roba.talaat@gebri.usc.edu.eg ) \\ GEBRI https://orcid.org/0000-0002-1176-2727
}

\section{Research Article}

Keywords: SLE, Treg, miRNAs, Active, Inactive

Posted Date: May 26th, 2021

DOI: https://doi.org/10.21203/rs.3.rs-531373/v1

License: @ (i) This work is licensed under a Creative Commons Attribution 4.0 International License. Read Full License 


\section{Abstract}

Various genetic factors are controlling regulatory cells T (Treg) cell function, such as miRNAs. Interfering in the miRNA synthesis pathway in Treg cells could result in loss of Tregs' regulatory function, leading to the promotion of inflammatory settings and autoimmunity. This study was designed to investigate the role of miRNA in regulating Treg cells in SLE patients. Treg's frequency was determined using flow cytometry in 100 SLE patients' and 100 healthy controls. Expression of miR-21, miR-24, miR125, miR-146a, miR-148a, and miR-155 was estimated in peripheral blood mononuclear cells (PBMCs) using quantitative real-time polymerase chain reaction (qRT-PCR). The ROC curve evaluated the diagnostic role of miRNAs in SLE. A significant elevation ( $p<0.001)$ in Treg cells in SLE patients than controls was observed, with a maximum increase inactive SLE cases. SLE patients exhibit a significant increase in miR-21 $(p<0.01)$, miR-148a $(p<0.001), \operatorname{miR}-146 a(p<0.05)$ and miR-155 $(p<0.001)$ and significant reduction in miR-24 $(p<0.001)$. An insignificant decrease in miR-125 was observed in SLE patients. The best sensitivity and specificity were detected in miR-148a (88\%, 70\%) at a cutoff value of 1.065 . Tregs were positively correlated with miR-21 $(r=0.333$, $p<0.05)$, miR-146a $(r=0.589, p<0.01)$ and miR-148a $(r=0.309, p<0.05)$. In conclusion, this research provides a piece of novel information regarding Treg cells' in SLE patients. Our results pointed to the substantial role of miRNAs in controlling Treg cells in lupus. To validate our interesting results, more researches are needed.

\section{Introduction}

Systemic lupus erythematosus (SLE) is a serious autoimmune multisystem disorder characterized by a lack of self-antigen immune tolerance, resulting in the continuous development of pathogenic autoantibodies, lymphocyte activation, and release of inflammatory mediators[1-3]. The subsequent production of autoantibodies by autoreactive $B$ cells is one of the main pathological factors in SLE, contributing to the production and deposition of immune-complexes leading to tissue damage [4-6].Both pathogenesis and autoantibody formation are dependent upon CD $4^{+} T$ cells [7].Based on cytokine patterns, naive CD4 + T cells can be divided into multiple subsets, including Th1, Th2, Th17, and Regulatory T cells (Treg) [7, 8].

Tregs $\left(C D 4^{+} \mathrm{CD} 25^{+} \mathrm{FOXP}^{+}\right)$cells are a specialized type of $\mathrm{T}$ cells that suppress the immune response, thereby maintaining homeostasis and self-tolerance [9]. It plays a vital role in the tolerance induction and sanctuary against autoimmunity [11, 12].Treg cells regulate the inflammatory activity $[12,13]$ by suppressing the effector $T$ cells and inducing the release of antiinflammatory as well as tissue repair cytokines [e.g., transforming growth factor- $\beta$ (TGF- $\beta$ ), interleukin-10 (IL-10) and IL-35]. TGF- $\beta$, working together with IL-10 to induce Treg differentiation from naïve T cells [14]. The equilibrium between the effector and regulatory $T$ cells determines whether an autoimmune response can be triggered and propagated by autoreactive cells or not [12]. While a great deal of effort has been made to shed some light on the Treg imbalance in SLE, contradictory results have been shown [15-24].

Treg cells' epigenetic regulation's molecular mechanism is crucial for understanding SLE pathogenesis. MicroRNAs (miRNAs) are small (only 21-25 nucleotide long) regulatory non-coding RNA molecules which are function as an epigenetic regulator of gene expression and play important roles in various physiologic and pathologic processes [25]. Compared to conventional T cells, Tregs display a distinguished miRNA profile [26]. Via several mechanisms, single miRNA or miRNA clusters could participate in Treg biology [27]. Differentiation, suppressive function, and persistence of thymically derived (tTreg) and periphery-induced ( $\mathrm{pTreg}$ ) or in vitro (iTreg) regulatory T cells might be driven by miRNAs [28-30]. Even the expression of the Treg transcription factor, Foxp3, is based on a particular miRNA profile. Besides, it is now commonly accepted that Foxp3 expression does not grant a terminal differentiation state, and Tregs are malleable, and miRNAs are needed to incorporate the external signals that drive these phenomena [31, 32].

Knowing that abnormalities either in the number or function of Treg cells are associated with the pathogenesis of autoimmune diseases and grasping further pieces of information about changes in certain factors; immunological and 
epigenetic, that coordinate the possible divergence of immune cells in lupus, our work performed a flow cytometric analysis of CD4 + CD25 + FOXP3 + Treg cells in SLE patients at various stages of disease activity. The potential impact of multiple expression profiles of microRNAs (miR-21, $-24,-125,-146 a,-148 a$, and -155) on Treg cells was also examined.

\section{Patients And Methods}

\subsection{SLE patients and healthy controls}

Our study included 100 consecutive patients who met the American College of Rheumatology (ACR) criteria for diagnosing SLE $[33,34]$. They were outpatients at the Rheumatology Department at El-Eini Hospitals, Cairo University, Egypt. The mean duration of SLE was $6.97 \pm 5.73$ years. Disease activity was assessed for all the lupus patients on the day of blood sampling by the SLE disease activity index (SLEDAI), and they were divided into active (SLEDAI score $\geq 6$ ) and inactive (a SLEDAl score of $<6$ ) [35]. The exclusion was made for patients with concomitant malignant diseases, infections, diabetes, abnormal lipid profile, and pregnant women.

One hundred participants matched by age and sex were enrolled as a normal control group with no history of autoimmune disorders or immunosuppressive drug treatment. Through a standardized interview and physical examination, demographic and clinical characteristics were collected. The local Ethics Committee of Cairo University confirmed the study plan. Both patients and healthy controls agreed to participate in this research, and all had received informed consent.

Based on their clinical status, SLE patients were divided into groups with active or inactive organ involvement. Patients were divided based on clinical manifestation into SLE patients with: skin involvement (lupus rash), photosensitivity (discoid lupus); active joint involvement (arthritis with synovial swelling), active hematologic involvement (thrombocytopenia, lymphocytopenia, or leukocytopenia or hemolytic anemia); active renal involvement (nephritis with proteinuria $>0.5 \mathrm{~g}$ protein/24 $\mathrm{h}$ and/or active nephritic sediment).

\subsection{Flow cytometric detection of T-lymphocytes}

In sterile ethylenediaminetetraacetic acid (EDTA) tubes, $5 \mathrm{ml}$ of venous blood were withdrawn. Ficoll-Hypaque separating media (Biowest SAS, Nuaillé, France) was used to isolate human peripheral blood mononuclear cells (PBMCs) from the blood, and Treg cells were identified using multiple staining's with three monoclonal antibodies against CD4, CD25, and FOXP3 as previously described [36, 37].

\subsection{RNA extraction and quantification of miRNA expression levels}

RNA was extracted from PBMCs of all participants using a TRIzol-based miRNA isolation kit (Life Technologies Ltd. UK)as described in the manufacturer's instructions. The purity and concentration of RNA were spectrophotometrically assessed by NanoDrop $^{\text {TM }} 2000 / 2000$ c (Thermo Fisher Scientific, Waltham, MA, USA). The RNA integrity was checked by $1 \%$ agarose gel electrophoresis.

miRNAs expression was analyzed using quantitative real-time polymerase chain reaction (qRT-PCR). miScriptll RT Transcription Kit (QIAGEN Valencia, CA, United States) is used to transcribe $100 \mathrm{ng}$ RNA from each sample to cDNA. The reaction was performed at $37^{\circ} \mathrm{C}$ for $60 \mathrm{~min}$, followed by incubation at $95^{\circ} \mathrm{C}$ for $5 \mathrm{~min}$ to inactivate the enzyme. Expression of Hs_miR-21, Hs_miR-24, Hs_miR-125a, Hs_miR-146a, Hs_miR-148a, and Hs_miR-155 was measured using miScript SYBR Green PCR Kit (Qiagen) and miScript Primer Assays (Qiagen) according to the supplemented protocol. The PCR cycling conditions were performed in AriaMx Real-Time PCR System (Agilent Technologies, Santa Clara, CA, USA) as follow: $95^{\circ} \mathrm{C}$ for $15 \mathrm{~min}$ for initial denaturation, followed by 40 cycles at $95^{\circ} \mathrm{C}$ for $15 \mathrm{~s}$ for denaturation, $55^{\circ} \mathrm{C}$ for $30 \mathrm{~s}$ for annealing and $72^{\circ} \mathrm{C}$ for $30 \mathrm{~s}$ for an extension, and a final stage were $95^{\circ} \mathrm{C}$ for $15 \mathrm{~s}, 60^{\circ} \mathrm{C}$ for $1 \mathrm{~min}$ and $95^{\circ} \mathrm{C}$ for $15 \mathrm{~s}$. As endogenous housekeeping control, SNORD68 and U6B small nuclear RNA (RNU6B) expression were used for data normalization. All calculations of miRNA expression levels were done as previously reported by El-Maadawy et al. [37]. 


\subsection{Statistical analysis}

SPSS 21.0 was used for all statistical analysis. Where applicable, data were statistically defined in terms of mean, standard error (SE), or frequencies. The Student's T-test for statistical analysis of parametric data and the Mann-Whitney U test for non-parametric data were used. Comparisons between groups were made using a one-way analysis of variance (ANOVA).By a receiver operating characteristic (ROC) curve, sensitivity versus the false positive frequency (one-specificity) for miRNAs was analyzed. Person's or Spearman's correlation test was used to assessing the correlation between variables. All twosided values with a P-value of less than 0.05 were considered. significant.

\section{Results}

\subsection{Demographic, biochemical, and clinical characteristic of SLE patients}

The present study was conducted on 100 SLE patients; 87 women and 13 men. Their mean age was $32.8 \pm 1.0$ years. One hundred healthy individuals were run in parallel (85 females and 15 males, with mean age $27.22 \pm 7.90$ ). All patients and controls were examined for the biochemical parameters associated with the disease. Table (1) summarized demographic and biochemical data of both patients and controls. The detailed clinical characteristics were summarized in Table (2). The mean disease activity for all patients was $9.37 \pm 9.01$. Based on the SLEDAI score, SLE patients were divided into 41 active patients (41\%) and 59 patients in an inactive state (59\%).

\subsection{Detection of Treg cells by flow cytometry}

Figure (1) showed the dot-plots representative of flow cytometric analysis of Treg cells. A significant elevation in the percentage of Treg cells $(p<0.001)$ in SLE patients when compared with healthy controls was observed (Fig. 2). Our results showed a significant increase in active and inactive patients $(p<0.001$ and $p<0.05$, respectively) compared to healthy controls with a maximum elevation in inactive ones. Although active SLE patients have more Treg than inactive patients, this increase is statistically insignificant.

\section{3. miRNAs expression levels in SLE}

As an overview of the whole lupus patients, our data showed a significant diminution in the expression ofmiR-24 in SLE patients compared to healthy controls $(p<0.001)$. miR-125 was also decreased in SLE patients but insignificantly. On the other side, miR-21, miR-146a, miR-148a and miR-155 were significantly elevated $(p<0.01, p<0.05, p<0.001$ andp $<0.001$; respectively) in lupus patients in relation to normal controls. Concerning the activity of the disease, our data showed a reduction in miR-24 and miR-125 and elevation in miR-21, miR-146a, miR-148a, and miR-155 in both groups (Fig. 3) as compared with normal controls. Regarding active and inactive SLE patients, no significant changes were found in the expression of miRNAs (miR-24 and miR-125 and elevation in miR-21, miR-146a, miR-148a, and miR-155) between both groups.

As shown in Figure (4); positive correlations were found in lupus patients between miR-21 and 3 miRNAs [miR146a $(r=$ $0.438 ; p<0.0015)$, miR-148a $(r=0.320 ; p<0.001)$ and miR-155 $(r=0.255 ; p<0.01)$ ]. Moreover, direct correlation between miR-24 and miR-125 ( $r=0.306 ; p<0.001)$ and between miR-148a and miR-155 ( $r=0.0351 ; p<0.001)$ were demonstrated in SLE patients. On the other hand, there was a negative correlation between miR-24 and miR-148a $(r=-0.178 ; p<0.05)$.

To distinguish between SLE patients and healthy control groups, we used ROC curve analysis to estimate the cutoff value for all calculated miRNAs (Fig. 5).According to the ROC curve results, the highest value of the area under the curve (AUC) was found in miR-148a(0.806), followed by miR-155 (0.764), and finally miR-21 (0.625). The highest levels of sensitivity and specificity were discovered (Table 3 ). The best sensitivity and specificity were detected in miR-148a (88\% and 70\%; respectively) at a cutoff value of 1.065 (Table 3 ). 


\subsection{Correlation between miRNAs and T-lymphocytes}

Tregs were directly correlated with miR-21 $(r=0.333, p<0.05)$, miR-146a $(r=0.589, p<0.01)$ and miR-148a $(r=0.309, p<$ 0.05).

\subsection{Association between SLE clinical manifestations and miRNAs and Tregs.}

The association between SLE clinical disease manifestations and miRNAs secretion levels was demonstrated (Table 4). Patients with renal manifestations or neutropenia had significantly higher levels of miR-21 $(p<0.01$ and $p<0.05$, respectively), while SLE patients with Raynauds phenomena had a significantly lower expression of miR-21 $(p<0.05)$ compared with those without these phenomena. SLE patients with serositis or renal disorder had significantly higher levels of miR-24 ( $p<0.001$ and $p<0.05$, respectively) compared to patients without these manifestations. Vasculitis manifestation was accompanied by a significant elevation $(p<0.01)$ of miR-125. Significantly elevated levels of miR-146a were reported in SLE patients with photosensitivity or lymphopenia $(p<0.05)$. Lupus patients with neutropenia had significantly higher levels of miR-155 than SLE patients without this manifestation $(p<0.05)$. We found a remarkable observation in miR-148a, which is significantly elevated $(p<0.01)$ in all hematological abnormalities (leucopenia, neutropenia, or lymphopenia) in addition to vasculitis $(p<0.01)$, serositis $(p<0.01)$, or renal manifestations $(p<0.01)$.

According to the type of treatment (Table 5), SLE patients treated with Endoxan, Imuran, and biologic had significantly higher levels $(p<0.01)$ of miR-21 compared to SLE patients without these treatments. A reduction in miR-125 $(p<0.001)$, miR-146a $(p<0.01)$, and miR-155 ( $<0.05)$ was observed in response to the treatment with Endoxan, Imuran, and Biologic.

A significant increase in Treg cells was observed in SLE patients with photosensitivity $(p<0.01)$ and with Raynauds $(p<$ 0.001 ) as compared with patients without these manifestations (Table 6). Alternatively, Treg cells didn't show any statistical significance with the other clinical manifestations of the disease or any treatment regimens.

\section{Discussion}

Tregs suppress self-reactive $T$ cells and inhibit their number and functions, helping to maintain peripheral tolerance and prevent the onset of autoimmune diseases $[38,39]$. Tregs suppress the functions of a number of cell types, including CD $4+$ TH cells, B cells, CD8 + cytotoxic T lymphocytes (CTLs), and antigen-presenting cells(APC), to effectively block immune responses, inflammation, and tissue destruction [40-42]. In the present study, alteration in Treg cells' frequency in SLE has been analyzed in the light of miRNAs expression, which possibly influences Tregs.

Our study observed a substantial increase in Treg cells in both active and inactive SLE patients compared to controls, with the most significant increase in active ones. This result agreed with Singla et al.'s(2017) [43] results, who reported a significant increase in Tregs in childhood SLE and mentioned that active lupus patients had a higher percentage than inactive lupus patients do. A previous study by Suarezet al. (2006)[44] also observed a significant elevation in both active and inactive SLE patients with a maximum increase in inactive ones. In contrast, Kailashiya et al. (2019)[45]found an insignificant difference in Treg cells' percentage in SLE patients. Knowing that corticosteroids (glucocorticoids and cyclophosphamide) were used as a regular treatment of lupus due to their suppressing effect on the immune response, specifically the development of pro-inflammatory cytokines, the observed rise in Tregs in our SLE patient might be returned to the impact of immunosuppressive therapies. These therapeutics have been proven to augment Tregs frequency in several conditions, including lupus [46-49].

Several miRNAs have been discovered to be essential in immune homeostasis. The role of microRNAs in immune cell lineage differentiation and their physiological functions in maintaining normal innate and adaptive responses is well known $[50,51]$. Aberrations in the miRNA-mediated immune-cell development and function regulation have been related to 
autoimmune diseases [52-54]. Intuitively, miRNA dysregulation is one of the main contributors to the collapse of selftolerance, leading to autoimmunity [55].

In the current study, there was a lowering in miR-125a expression level in both active and inactive phases of the disease compared to the healthy group. These findings agree with Zhaoet al. (2010) [56] and Wang et al. (2012) [57], who reported a reduction in miR-125 level in SLE patients. In T cells isolated from lupus patients, diminished levels of miR-125a had been reported [58]. miR-125a promotes the up-regulation of the inflammatory chemokine RANTES, which is needed for the adverse effects of inflammatory processes. Its deficiency impairs Treg maintenance and immunoregulatory capacity, while over expression of miR-125a stabilizes Treg-mediated self-tolerance [59].

A significant diminution in miR-24 expression levels was observed in SLE patients, either active or inactive, compared to normal controls. No previous studies have been performed on the change in miR-24 level in lupus patients to the best of our knowledge. Murata et al. (2013)[58] reported an increase in the expression level of miR-24 in Rheumatoid Arthritis (RA) patients. Both miR-24 and miR-125a can play a role in the inflammation's enhancement. Via direct targeting of Furin, miR-24 might control the processing of latent transforming growth factor (TGF-1) [60], and miR-125 targets the tumor necrosis factor-alpha-induced protein 3 (TNFAIP3) [61]. TGF- $\beta 1$ plays a suppressive role in immune system regulation[62]. Moreover, furin expression in T-cells is also essential for maintaining peripheral immune tolerance $[63,58]$.

Our results recorded a significant elevation in miR-146a in active and inactive SLE patients compared to normal controls. Our data agree with Chen et al. (2017) [64] and Zheng et al. (2017) [65], who observed over expression of miR-146a in SLE patients. On the other hand, Luo et al. (2011) [66] reported a reduction in miR-146a expression in lupus patients. The TLR4/NFB signaling pathway is negatively regulated by miR146a, and its down regulation causes inflammatory responses to be activated. Over expression of miR-146a reduced TRAF6 and consequently inhibited the activity of NF-KB, resulting in simultaneous inhibition of TNF-a, IL-1 $\beta$, and IL-8 synthesis [67].

Similar to previously published studies of Chen et al. (2017) [64] and Shumnalieva et al. (2018) [68] who found over expression of miR-155 in SLE patients; our data showed a significant increase miR-155 in the peripheral blood of SLE patients with a maximum elevation in inactive patients. This data disagrees with Wang et al. (2012) [57], who reported an unexpected reduction in the expression level of miR-155 in SLE patients. Over expression of miR-155 contributes to the development of antibodies, irregular T cell differentiation, kidney failure, and lupus-like symptoms [69, 70]. Some miRNAs, such as miR-155, commonly associated with a compromised immune response and increases disease activity, were differentially expressed in multiple autoimmune diseases [71].

We demonstrated a significant increase in miR-21 was observed in both active and inactive status of the disease compared to healthy controls. In accordance with this data, the study of Wanget al. (2012)[57] on SLE patients pointed to the upregulation of miR-21 expression in SLE patients. The same observation was previously mentioned by Pan et al. (2010) [72], who observed a significant increase in miR-21.In accordance, patients with active disease have substantially higher levels of miR-21 in their PBMC than normal subjects and patients with inactive disease [73]. Elevated miR-21 levels promoted CD4 + T cell activation, B cell hyper-responsiveness, and over expression of autoimmune-associated methylation-sensitive genes through repression of DNMT1, PDCD4, or PTEN expression [72, 74, 75]. Besides, the inhibition of miR-21 in CD4 + T cells from SLE patients might reverse T cells' activation $[74,76]$.

A significant elevation in miR-148a expression levels in SLE patients was observed in the present study, with the maximum increase in the active group. This finding was in agreement with Wang et al. (2012) [57] and Chen et al. (2017) [64], who observed an increase in miR-148alevel in SLE patients. Moreover, our finding was consistent with Pan et al. (2010)[72], who observed that miR-148a was up-regulated in SLE patients. miR-148a expression was up-regulated in $\mathrm{CD}^{+}{ }^{+} \mathrm{T}$ cells from patients with SLE patient. miR-21, miR-126, and miR-148a over-expression resulted in DNA hypomethylation in CD $4+\mathrm{T}$ cells by direct inhibition of DNMT1 protein expression, thus inducing CD4 + T cell activation and secretion of autoimmune-related proteins, such as CD70, CD11a, and LFA-1[72, 77, 76].In females, DNA methylation serves as a housekeeping mechanism 
for physiological X-chromosome inactivation [78-81].It might be estimated that increased circulating miR-21 and miR-148a, in turn, might also accelerate disease progression through the cell-cell communication processes between these apoptotic bodies, exosomes, and target cells, such as quiescent lymphocytes[76]. Zhang et al. (2020)[71] pointed to the elevation of miR-148a, which is generally associated with the immune response and increases the disease's activity.

In conclusion, we approved the numeric rising in Treg cells' frequency in SLE patients, especially those in an active state. Although, we stressed the idea that these elevated cells might be malfunctioning. Studying the expression of some miRNAs associated with Treg cells pointed to the increase in miR146a, miR155 miR148a, and miR-21, coinciding with the reduction of miR-24. We hypothesized that the increase in miR-21, miR-148a, and miR-155 (Treg positive regulators) accompanied by a decrease of miR-24 (Treg negative regulators) favors the elevation of Treg cells, leading to this observed increase of Treg cell frequency. There is a lack of consensus in the research on the relationship between Treg and rheumatic diseases. The majority of evidence proposes Treg cells' impairment, quantitatively and/or qualitatively. Herein, our results provide a novel insight into Treg-miRNA's role in lupus patients' regulation network.

However, our study has some potential limitations, such as the lack of previous studies on some miRNAs in SLE patients (such as miR-24) and using a sorter to test the function of detected Treg cells. Thus, further studies are needed to confirm our findings. We performed the same research on another important autoimmune disease (RA) to examine our assumption's strength in view of this hope.

\section{Declarations}

Conflict of interest: The authors declare that they have no conflict of interest.

Funding source: This study was supported by research funds from the Science and Technological Development Fund (STDF), Egyptian Ministry for Scientific Research (Grant No: 15123).

Availability of data and material: Data available by corresponding author on request.

Informed consent: All patients and healthy controls agreed to be enrolled in this study, and informed consent was obtained from all participants.

\section{References}

1. -Poole BD, Niewold TB, Tsokos GC. Cytokines in systemic lupus erythematosus 2011. J Biomed Biotechnol. 2012;2012:427824. doi:10.1155/2012/427824. Epub 2011 Dec 29. PMID: 22505810; PMCID: PMC3312291.

2. -Cheng HB, Chen RY, Wu JP, et al. Complement $\mathrm{C} 4$ induces regulatory $T$ cells differentiation through dendritic cell in systemic lupus erythematosus. Cell Biosci. 2015 Dec 23;5:73. doi: 10.1186/s13578-015-0052-8. PMID: 26705467; PMCID: PMC4690337.

3. -Justiz Vaillant AA, Goyal A, Bansal P, Varacallo M. Systemic Lupus Erythematosus (SLE). 2020 Aug 10. In: StatPearls [Internet]. Treasure Island (FL): StatPearls Publishing; 2020 Jan-. PMID: 30571026.

4. -Wang S, Wang J, Kumar V, et al. IL-21 drives expansion and plasma cell differentiation of autoreactive CD11chiT-bet + B cells in SLE. Nat Commun. 2018 May 1;9(1):1758. doi: 10.1038/s41467-018-03750-7. PMID: 29717110; PMCID: PMC5931508.

5. -Wang Y, Yuan J, Dai D, et al. Poly IC pretreatment suppresses B cell-mediated lupus-like autoimmunity through induction of Peli1. Acta Biochim Biophys Sin (Shanghai). 2018 Sep 1;50(9):862-868. doi: 10.1093/abbs/gmy082. PMID: 30032173.

6. -Hamilton JA, Hsu HC, Mountz JD. Autoreactive B cells in SLE, villains or innocent bystanders? Immunol Rev. 2019 Nov;292(1):120-38. doi:10.1111/imr.12815. Epub 2019 Oct 21. PMID: 31631359; PMCID: PMC6935412. 
7. -Ma J, Yu J, Tao X, Cai L, Wang J, Zheng SG. The imbalance between regulatory and IL-17-secreting CD $4+T$ cells in lupus patients. Clin Rheumatol. 2010 Nov;29(11):1251-8. doi:10.1007/s10067-010-1510-7. Epub 2010 Jun 19. PMID: 20563617.

8. -Nguyen QP, Deng TZ, Witherden DA, Goldrath AW. Origins of CD4 + circulating and tissue-resident memory T-cells. Immunology. 2019 May;157(1):3-12. doi:10.1111/imm.13059. PMID: 30897205; PMCID: PMC6459775.

9. -Kondělková K, Vokurková D, Krejsek J, Borská L, Fiala Z, Ctirad A. Regulatory T cells (TREG) and their roles in immune system with respect to immunopathological disorders. Acta Medica (Hradec Kralove). 2010;53(2):73 - 7. doi: 10.14712/18059694.2016.63. PMID: 20672742.

10. -Rudensky AY. Regulatory T. cells and Foxp3. Immunol Rev. 2011 May;241(1):260-8. doi: 10.1111/j.1600065X.2011.01018.x. PMID: 21488902; PMCID: PMC3077798.

11. -Sawla P, Hossain A, Hahn BH, Singh RP. Regulatory T cells in systemic lupus erythematosus (SLE); role of peptide tolerance. Autoimmun Rev. 2012 Jul;11(9):611-4. doi:10.1016/j.autrev.2011.09.008. Epub 2011 Oct 7. PMID: 22001419.

12. -Astry B, Venkatesha SH, Moudgil KD. Involvement of the IL-23/IL-17 axis and the Th17/Treg balance in the pathogenesis and control of autoimmune arthritis. Cytokine. 2015 Jul;74(1):54-61. doi:10.1016/j.cyto.2014.11.020. Epub 2015 Jan 13. PMID: 25595306; PMCID: PMC4457562.

13. -Wang D, Lei L. Interleukin-35 regulates the balance of Th17 and Treg responses during the pathogenesis of connective tissue diseases. Int J Rheum Dis. 2020 Sep 11. doi: 10.1111/1756-185X.13962. Epub ahead of print. PMID: 32918357.

14. -Kuwabara T, Ishikawa F, Kondo M, Kakiuchi T. The Role of IL-17 and Related Cytokines in Inflammatory Autoimmune Diseases. Mediators Inflamm. 2017;2017:3908061. doi: 10.1155/2017/3908061. Epub 2017 Feb 20. PMID: 28316374; PMCID: PMC5337858.

15. -Bonelli M, Savitskaya A, von Dalwigk K, et al. Quantitative and qualitative deficiencies of regulatory $T$ cells in patients with systemic lupus erythematosus (SLE). Int Immunol. 2008 Jul;20(7):861-8. doi:10.1093/intimm/dxn044. Epub 2008 May 9. PMID: 18469329.

16. -Bonelli M, Smolen JS, Scheinecker C. Treg and lupus. Ann Rheum Dis. 2010 Jan;69 Suppl 1:i65-66. doi: 10.1136/ard.2009.117135. PMID: 19995748.

17. -Alunno A, Bartoloni E, Bistoni O, et al. Balance between regulatory T and Th17 cells in systemic lupus erythematosus: the old and the new. Clin Dev Immunol. 2012;2012:823085. doi:10.1155/2012/823085. Epub 2012 Jun 14. PMID: 22761634; PMCID: PMC3386568.

18. -Bonelli M, Göschl L, Blüml S, et al. CD4â๊ ${ }^{\circ} \mathrm{CD} 25 a ̂ \rrbracket » F o x p 3 a ̂ \square^{\circ}$ T cells: a marker for lupus nephritis? Arthritis Res Ther. 2014 Apr 28;16(2):R104. doi: 10.1186/ar4553. PMID: 24774748; PMCID: PMC4060257.

19. -Eltayeb AA, Sayed DM, Afifi NA, Ibrahim MA, Sheref TM. Regulatory T cell subsets in children with systemic lupus erythematosus. Clin Rheumatol. 2014 Aug;33(8):1085-91. doi:10.1007/s10067-014-2636-9. Epub 2014 May 27. PMID: 24863846.

20. -Singla S, Wenderfer SE, Muscal E, Sagcal-Gironella ACP, Orange JS, Makedonas G. Changes in Frequency and Activation Status of Major CD4 + T-Cell Subsets after Initiation of Immunosuppressive Therapy in a Patient with New Diagnosis Childhood-Onset Systemic Lupus Erythematosus. Front Pediatr. 2017 May 15;5:104. doi: 10.3389/fped.2017.00104. PMID: 28555177; PMCID: PMC5430328.

21. -Yin ZJ, Ju BM, Zhu L, et al. Increased CD4 + CD25-Foxp3 + T cells in Chinese systemic lupus erythematosus: correlate with disease activity and organ involvement. Lupus. 2018 Nov;27(13):2057-2068. doi: 10.1177/0961203318804881. Epub 2018 Oct 18. PMID: 30336752.

22. -Taylor EB, Sasser JM, Maeda KJ, Ryan MJ. Expansion of regulatory T cells using low-dose interleukin-2 attenuates hypertension in an experimental model of systemic lupus erythematosus. Am J Physiol Renal Physiol. 2019 Nov 1;317(5):F1274-F1284. doi: 10.1152/ajprenal.00616.2018. Epub 2019 Mar 20. PMID: 30892934; PMCID: PMC6879936. 
23. -Zhao C, Chu Y, Liang Z, et al. Low dose of IL-2 combined with rapamycin restores and maintains the long-term balance of Th17/Treg cells in refractory SLE patients. BMC Immunol. 2019 Sep 4;20(1):32. doi: 10.1186/s12865-019-0305-0. PMID: 31484501; PMCID: PMC6727508.

24. -Darlan DM, Munir D, Putra A, Jusuf NK. MSCs-released TGF $\beta 1$ generate CD 4 + CD 25 + Foxp3 + in T-reg cells of human SLE PBMC. J Formos Med Assoc. 2020 Jul 24:S0929-6646(20)30288-6. doi: 10.1016/j.jfma.2020.06.028. Epub ahead of print. PMID: 32718891.

25. -Jin F, Hu H, Xu M, et al. Serum microRNA Profiles Serve as Novel Biomarkers for Autoimmune Diseases. Front Immunol. 2018 Oct 16;9:2381. doi: 10.3389/fimmu.2018.02381. PMID: 30459760; PMCID: PMC6232775.

26. -Bhairavabhotla R, Kim YC, Glass DD, et al. Transcriptome profiling of human FoxP3 + regulatory T cells. Hum Immunol. 2016 Feb;77(2):201-13. doi:10.1016/j.humimm.2015.12.004. Epub 2015 Dec 10. PMID: 26686412; PMCID: PMC4761514.

27. -Winter SJ, Krueger A. Development of Unconventional T Cells Controlled by MicroRNA. Front Immunol. 2019 Oct 23;10:2520. doi: 10.3389/fimmu. 2019.02520. PMID: 31708931; PMCID: PMC6820353.

28. -Tang X, Tang R, Xu Y, et al. MicroRNA networks in regulatory T cells. J Physiol Biochem. 2014 Sep;70(3):869-75. doi:10.1007/s13105-014-0348-x. Epub 2014 Aug 10. PMID: 25108555.

29. -Buoli Comani G, Panceri R, Dinelli M, et al. miRNA-regulated gene expression differs in celiac disease patients according to the age of presentation. Genes Nutr. 2015 Sep;10(5):482. doi: 10.1007/s12263-015-0482-2. Epub 2015 Aug 2. PMID: 26233308; PMCID: PMC4522246.

30. -Jasinski-Bergner S, Stoehr C, Bukur J, et al. Clinical relevance of miR-mediated HLA-G regulation and the associated immune cell infiltration in renal cell carcinoma. Oncoimmunology. 2015 Mar 2;4(6):e1008805. doi: 10.1080/2162402X.2015.1008805. PMID: 26155421; PMCID: PMC4485830.

31. -Lu L, Barbi J, Pan F. The regulation of immune tolerance by FOXP3. Nat Rev Immunol. 2017 Nov;17(11):703-17. doi:10.1038/nri.2017.75. Epub 2017 Jul 31. PMID: 28757603; PMCID: PMC5793224.

32. -Hippen KL, Loschi M, Nicholls J, MacDonald KPA, Blazar BR. Effects of MicroRNA on Regulatory T Cells and Implications for Adoptive Cellular Therapy to Ameliorate Graft-versus-Host Disease. Front Immunol. 2018 Jan 31;9:57. doi: 10.3389/fimmu.2018.00057. PMID: 29445371; PMCID: PMC5797736.

33. -Hartman EAR, van Royen-Kerkhof A, Jacobs JWG, Welsing PMJ, Fritsch-Stork RDE. Performance of the 2012 Systemic Lupus International Collaborating Clinics classification criteria versus the 1997 American College of Rheumatology classification criteria in adult and juvenile systemic lupus erythematosus. A systematic review and meta-analysis. Autoimmun Rev. 2018 Mar;17(3):316-322. doi: 10.1016/j.autrev.2018.01.007. Epub 2018 Jan 31. PMID: 29366725.

34. -Aringer M, Costenbader K, Daikh D, et al. 2019 European League Against Rheumatism/American College of Rheumatology Classification Criteria for Systemic Lupus Erythematosus. Arthritis Rheumatol 2019 Sep;71(9):1400-12. doi:10.1002/art.40930. Epub 2019 Aug 6. PMID: 31385462; PMCID: PMC6827566.

35. -Gatto M, Saccon F, Zen M, et al. Early Disease and Low Baseline Damage as Predictors of Response to Belimumab in Patients With Systemic Lupus Erythematosus in a Real-Life Setting. Arthritis Rheumatol. 2020 Aug;72(8):1314-24. doi:10.1002/art.41253. Epub 2020 Jun 12. PMID: 32275125.

36. -Talaat RM, Elmaghraby AM, Barakat SS, El-Shahat M. Alterations in immune cell subsets and their cytokine secretion profile in childhood idiopathic thrombocytopenic purpura (ITP). Clin Exp Immunol. 2014 May;176(2):291-300. doi:10.1111/cei.12279. PMID: 24460857; PMCID: PMC3992042.

37. -El-Maadawy EA, Elshal MF, Bakry RM, Moussa MM, El-Naby S, Talaat RM. Regulation of CD4 + CD25 + FOXP3 + cells in Pediatric Acute Lymphoblastic Leukemia (ALL): Implication of cytokines and miRNAs. Mol Immunol. 2020 Aug;124:1-8. doi: 10.1016/j.molimm.2020.05.002. Epub 2020 May 30. PMID: 32480291.

38. -Manjili MH, Payne KK. Immune Regulatory Function of Tregs. Immunol Invest. 2016 Nov;45(8):708-711. doi: 10.1080/08820139.2016.1235394. PMID: 27775448. 
39. -Kailashiya V, Singh U, Rana R, Singh NK, Dash D, Kailashiya J. Regulatory T Cells and Their Association with Serum Markers and Symptoms in Systemic Lupus Erythematosus and Rheumatoid Arthritis. Immunol Invest. 2019 Jan;48(1):64-78. doi: 10.1080/08820139.2018.1527852. Epub 2018 Oct 16. PMID: 30325682.

40. -Taams LS, Boot EP, van Eden W, Wauben MH. 'Anergic' T cells modulate the T-cell activating capacity of antigenpresenting cells. J Autoimmun. 2000 Jun;14(4):335 - 41. doi: 10.1006/jaut.2000.0372. PMID: 10882060.

41. -Eddahri F, Oldenhove G, Denanglaire S, Urbain J, Leo O, Andris F. CD4 + CD25 + regulatory T cells control the magnitude of T-dependent humoral immune responses to exogenous antigens. Eur J Immunol. 2006 Apr;36(4):855 - 63. doi: 10.1002/eji.200535500. PMID: 16511897.

42. -Mempel TR, Pittet MJ, Khazaie K, et al. Regulatory T cells reversibly suppress cytotoxic T cell function independent of effector differentiation. Immunity. 2006 Jul;25(1):129 - 41. doi: 10.1016/j.immuni.2006.04.015. PMID: 16860762.

43. -Singla S, Wenderfer SE, Muscal E, Sagcal-Gironella ACP, Orange JS, Makedonas G. Changes in Frequency and Activation Status of Major CD4 + T-Cell Subsets after Initiation of Immunosuppressive Therapy in a Patient with New Diagnosis Childhood-Onset Systemic Lupus Erythematosus. Front Pediatr. 2017 May 15;5:104. doi: 10.3389/fped.2017.00104. PMID: 28555177; PMCID: PMC5430328.

44. -Suárez A, López P, Gómez J, Gutiérrez C. Enrichment of CD4 + CD25high T cell population in patients with systemic lupus erythematosus treated with glucocorticoids. Ann Rheum Dis. 2006 Nov;65(11):1512-7.

doi:10.1136/ard.2005.049924. Epub 2006 Apr 10. PMID: 16606650; PMCID: PMC1798359.

45. -Kailashiya V, Singh U, Rana R, Singh NK, Dash D, Kailashiya J. Regulatory T Cells and Their Association with Serum Markers and Symptoms in Systemic Lupus Erythematosus and Rheumatoid Arthritis. Immunol Invest. 2019 Jan;48(1):64-78. doi: 10.1080/08820139.2018.1527852. Epub 2018 Oct 16. PMID: 30325682.

46. -Hayball JD, Lake RA. Altered superantigenic ligands demonstrate the quantitative nature of T-cell activation. Immunol Cell Biol. 2000 Dec;78(6):623 - 32. doi: 10.1046/j.1440-1711.2000.00971.x. PMID: 11114973.

47. -Karagiannidis C, Akdis M, Holopainen P, et al. Glucocorticoids upregulate FOXP3 expression and regulatory $T$ cells in asthma. J Allergy Clin Immunol. 2004 Dec;114(6):1425-33. doi: 10.1016/j.jaci.2004.07.014. PMID: 15577848.

48. -Fattorossi A, Battaglia A, Buzzonetti A, Ciaraffa F, Scambia G, Evoli A. Circulating and thymic CD4 CD25 T regulatory cells in myasthenia gravis: effect of immunosuppressive treatment. Immunology. 2005 Sep;116(1):134-41. doi:10.1111/j.1365-2567.2005.02220.x. PMID: 16108825; PMCID: PMC1802400.

49. -Azab NA, Bassyouni IH, Emad Y, Abd El-Wahab GA, Hamdy G, Mashahit MA. CD4 + CD25 + regulatory T cells (TREG) in systemic lupus erythematosus (SLE) patients: the possible influence of treatment with corticosteroids. Clin Immunol. 2008 May;127(2):151-7. doi: 10.1016/j.clim.2007.12.010. Epub 2008 Mar 4. PMID: 18299252.

50. -Turner ML, Schnorfeil FM, Brocker T. MicroRNAs regulate dendritic cell differentiation and function. J Immunol. 2011 Oct 15;187(8):3911-7. doi: 10.4049/jimmunol.1101137. PMID: 21969315.

51. -Mehta A, Baltimore D. MicroRNAs as regulatory elements in immune system logic. Nat Rev Immunol. 2016 Apr 28;16(5):279 - 94. doi: 10.1038/nri.2016.40. PMID: 27121651.

52. -Luo X, Tsai LM, Shen N, Yu D. Evidence for microRNA-mediated regulation in rheumatic diseases. Ann Rheum Dis. 2010 Jan;69 Suppl 1:i30-36. doi: 10.1136/ard.2009.117218. PMID: 19995741.

53. -Mao X, Su Z, Mookhtiar AK. Long non-coding RNA: a versatile regulator of the nuclear factor-kB signalling circuit. Immunology. 2017 Apr;150(4):379-88. doi:10.1111/imm.12698. Epub 2017 Jan 19. PMID: 27936492; PMCID: PMC5343356.

54. -Liu C, Li N, Liu G. The Role of MicroRNAs in Regulatory T Cells. J Immunol Res. 2020 Apr 2;2020:3232061. doi: 10.1155/2020/3232061. PMID: 32322593; PMCID: PMC7154970.

55. -Lam IKY, Chow JX, Lau CS, Chan VSF. MicroRNA-mediated immune regulation in rheumatic diseases. Cancer Lett. 2018 Sep 1;431:201-212. doi: 10.1016/j.canlet.2018.05.044. Epub 2018 May 31. PMID: 29859876. 
56. -Zhao X, Tang Y, Qu B, et al. MicroRNA-125a contributes to elevated inflammatory chemokine RANTES levels via targeting KLF13 in systemic lupus erythematosus. Arthritis Rheum. 2010 Nov;62(11):3425-35. doi: 10.1002/art.27632. PMID: 20589685.

57. -Wang H, Peng W, Ouyang X, Li W, Dai Y. Circulating microRNAs as candidate biomarkers in patients with systemic lupus erythematosus. TransI Res. 2012 Sep;160(3):198-206. doi: 10.1016/j.trsl.2012.04.002. Epub 2012 May 4. PMID: 22683424.

58. -Murata K, Furu M, Yoshitomi H, et al. Comprehensive microRNA analysis identifies miR-24 and miR-125a-5p as plasma biomarkers for rheumatoid arthritis. PLoS One. 2013 Jul 18;8(7):e69118. doi: 10.1371/journal. pone.0069118. PMID: 23874885; PMCID: PMC3715465.

59. -Zhang J, Chen C, Fu H, et al. MicroRNA-125a-Loaded Polymeric Nanoparticles Alleviate Systemic Lupus Erythematosus by Restoring Effector/Regulatory T Cells Balance. ACS Nano. 2020 Apr 28;14(4):4414-4429. doi: 10.1021/acsnano.9b09998. Epub 2020 Mar 26. PMID: 32203665.

60. -Luna C, Li G, Qiu J, Epstein DL, Gonzalez P. MicroRNA-24 regulates the processing of latent TGF $\beta 1$ during cyclic mechanical stress in human trabecular meshwork cells through direct targeting of FURIN. J Cell Physiol. 2011 May;226(5):1407-14. doi:10.1002/jcp.22476. PMID: 20945401; PMCID: PMC3152464.

61. -Kim SW, Ramasamy K, Bouamar H, Lin AP, Jiang D, Aguiar RC. MicroRNAs miR-125a and miR-125b constitutively activate the NF-KB pathway by targeting the tumor necrosis factor alpha-induced protein 3 (TNFAIP3, A20). Proc Natl Acad Sci U S A. 2012 May 15;109(20):7865-70. doi: 10.1073/pnas.1200081109. Epub 2012 May 1. PMID: 22550173; PMCID: PMC3356650.

62. -Dons EM, Raimondi G, Cooper DK, Thomson AW. Induced regulatory T cells: mechanisms of conversion and suppressive potential. Hum Immunol. 2012 Apr;3(4):328-34. doi:10.1016/j.humimm.2011.12.011. Epub 2012 Jan 14. PMID: 22285847; PMCID: PMC3319286.

63. -Pesu M, Watford WT, Wei L, et al. T-cell-expressed proprotein convertase furin is essential for maintenance of peripheral immune tolerance. Nature. 2008 Sep 11;455(7210):246 - 50. doi: 10.1038/nature07210. PMID: 18701887; PMCID: PMC2758057.

64. -Chen JQ, Papp G, Póliska S, et al. MicroRNA expression profiles identify disease-specific alterations in systemic lupus erythematosus and primary Sjögren's syndrome. PLoS One. 2017 Mar 24;12(3):e0174585. DOI:

10.1371/journal.pone.0174585. PMID: 28339495; PMCID: PMC5365120.

65. -Zheng CZ, Shu YB, Luo YL, Luo J. The role of miR-146a in modulating TRAF6-induced inflammation during lupus nephritis. Eur Rev Med Pharmacol Sci. 2017 Mar;21(5):1041-8. PMID: 28338190.

66. -Luo X, Yang W, Ye DQ, et al. A functional variant in microRNA-146a promoter modulates its expression and confers disease risk for systemic lupus erythematosus. PLoS Genet. 2011 Jun;7(6):e1002128. doi: 10.1371/ journal.pgen.1002128. Epub 2011 Jun 30. PMID: 21738483; PMCID: PMC3128113.

67. -Loubaki L, Chabot D, Paré I, Drouin M, Bazin R. MiR-146a potentially promotes IVlg-mediated inhibition of TLR4 signaling in LPS-activated human monocytes. Immunol Lett. 2017 May;185:64-73. doi:10.1016/j.imlet.2017.02.015. Epub 2017 Mar 10. PMID: 28288804.

68. -Shumnalieva R, Kachakova D, Shoumnalieva-Ivanova V, Miteva P, Kaneva R, Monov S. Whole peripheral blood miR146a and miR-155 expression levels in Systemic lupus erythematosus patients. Acta Reumatol Port. 2018 JulSep;43(3):217-25. English. PMID: 30414370.

69. -Yan S, Yim LY, Tam RC, et al. MicroRNA-155 Mediates Augmented CD40 Expression in Bone Marrow Derived Plasmacytoid Dendritic Cells in Symptomatic Lupus-Prone NZB/W F1 Mice. Int J Mol Sci. 2016 Aug 6;17(8):1282. doi: 10.3390/ijms17081282. PMID: 27509492; PMCID: PMC5000679.

70. -Zan H, Tat C, Casali P. MicroRNAs in lupus. Autoimmunity. 2014 Jun;47(4):272-85. doi:10.3109/08916934.2014.915955. PMID: 24826805; PMCID: PMC4239026. 
71. -Zhang L, Wu H, Zhao M, Lu Q. Identifying the differentially expressed microRNAs in autoimmunity: A systemic review and meta-analysis. Autoimmunity. 2020 May;53(3):122-136. doi: 10.1080/08916934.2019.1710135. Epub 2020 Jan 6. PMID: 31902241.

72. -Pan W, Zhu S, Yuan M, et al. MicroRNA-21 and microRNA-148a contribute to DNA hypomethylation in lupus CD4 + T cells by directly and indirectly targeting DNA methyltransferase 1. J Immunol. 2010 Jun 15;184(12):6773-81. doi: 10.4049/jimmunol.0904060. Epub 2010 May 17. PMID: 20483747.

73. -Kourti M, Sokratous M, Katsiari CG. Regulation of microRNA in systemic lupus erythematosus: the role of miR-21 and miR-210. Mediterr J Rheumatol. 2020 Mar 31;31(1):71-74. doi: 10.31138/mjr.31.1.71. PMID: 32411934; PMCID: PMC7219647.

74. -Stagakis E, Bertsias G, Verginis P, et al. Identification of novel microRNA signatures linked to human lupus disease activity and pathogenesis: miR-21 regulates aberrant T cell responses through regulation of PDCD4 expression. Ann Rheum Dis. 2011 Aug;70(8):1496-506. doi: 10.1136/ard.2010.139857. Epub 2011 May 20. PMID: 21602271.

75. -Wu XN, Ye YX, Niu JW, et al. Defective PTEN regulation contributes to B cell hyperresponsiveness in systemic lupus erythematosus. Sci Transl Med. 2014 Jul 23;6(246):246ra99. doi: 10.1126/scitranslmed.3009131. PMID: 25101889.

76. Guo -Shuiming, Ge S, Ku M, et al. Clinical correlation of plasma miR-21, miR-126 and miR-148a in patients with lupus nephritis. Int J Clin Exp Med. 2016;9(2):2905-12.

77. -Zhao S, Wang Y, Liang Y, et al. MicroRNA-126 regulates DNA methylation in CD4 + T cells and contributes to systemic lupus erythematosus by targeting DNA methyltransferase 1. Arthritis Rheum. 2011 May;63(5):1376-86. doi: 10.1002/art.30196. PMID: 21538319.

78. -McMurray RW. Sex hormones in the pathogenesis of systemic lupus erythematosus. Front Biosci. 2001 Dec 1;6:E193206. doi: 10.2741/mcmurray. PMID: 11724682.

79. -Lu Q, Wu A, Tesmer L, Ray D, Yousif N, Richardson B. Demethylation of CD40LG on the inactive X in T cells from women with lupus. J Immunol. 2007 Nov 1;179(9):6352-8. doi: 10.4049/jimmunol.179.9.6352. PMID: 17947713.

80. -Khan D, Dai R, Ansar Ahmed S. Sex differences and estrogen regulation of miRNAs in lupus, a prototypical autoimmune disease. Cell Immunol. 2015 Apr;294(2):70-9. doi:10.1016/j.cellimm.2015.01.004. Epub 2015 Jan 19. PMID: 25619140.

81. -Tsai CY, Hsieh SC, Lu CS, et al. Cross-Talk between Mitochondrial Dysfunction-Provoked Oxidative Stress and Aberrant Noncoding RNA Expression in the Pathogenesis and Pathophysiology of SLE. Int J Mol Sci. 2019 Oct 19;20(20):5183. doi: 10.3390/ijms20205183. PMID: 31635056; PMCID: PMC6829370.

\section{Tables}

Table (1). Demographic and biochemical characteristics of controls and SLE patients. 


\begin{tabular}{|c|c|c|c|}
\hline Parameters & $\begin{array}{l}\text { Control } \\
(\mathrm{N}=100)\end{array}$ & $\begin{array}{l}\text { SLE } \\
(\mathrm{N}=100)\end{array}$ & $\begin{array}{l}\mathrm{P} \\
\text { value }\end{array}$ \\
\hline Age & $27.22 \pm 7.90$ & $32.8 \pm 1.0$ & NS \\
\hline Sex (female/male) & $85 / 15$ & $87 / 13$ & NS \\
\hline ESR & $6.2 \pm 0.2$ & $56.4 \pm 3.4$ & $P<0.01$ \\
\hline WBC (X1000/pl) & $8.0 \pm 0.14$ & $8.1 \pm 0.4$ & NS \\
\hline HGB (g/dl) & $13.2 \pm 0.14$ & $11.0 \pm 0.2$ & $P<0.01$ \\
\hline Platelets $(\mathrm{X} 1000 / \mu \mathrm{l})$ & $285.5 \pm 6.4$ & $257.1 \pm 12.3$ & $P<0.01$ \\
\hline Creatinine (mg/dl) & $0.9 \pm 0.23$ & $0.9 \pm 0.7$ & NS \\
\hline ALT (IU/L) & $21.09 \pm 0.6$ & $21.2 \pm 1.6$ & NS \\
\hline AST (IU/L) & $23.8 \pm 0.6$ & $23.5 \pm 1.5$ & NS \\
\hline
\end{tabular}

All data are presented as mean \pm standard Error (mean \pm SE). NS = not significant.

White Blood Cells (WBCs); Alanine aminotransferase (ALT); Aspartate aminotransferase (AST); ESR (erythrocyte sedimentation rate); HGB (Hemoglobin).

Table (2): Clinical and laboratory characteristics of SLE patients 


\begin{tabular}{|c|c|c|c|}
\hline Demographic data & Mean \pm SD & Laboratory Data & Mean \pm SD \\
\hline Age (years) & $32.75 \pm 10.31$ & Serum albumin & $3.19 \pm 0.7$ \\
\hline Disease duration (years) & $6.97 \pm 5.73$ & C3titre & $77.4 \pm 44.6$ \\
\hline Female/Male & $87 / 13$ & C4 titre & $20.6 \pm 24.3$ \\
\hline SLEDAI & $9.37 \pm 9.01$ & Cholestrol & $187.5 \pm 72.1$ \\
\hline ACR criteria of SLE & № $(\%)$. & Treiglyceride & $162.97 \pm 92.9$ \\
\hline Malar rash & $73(72.3)$ & $\mathrm{HDL}$ & $47.2 \pm 12.9$ \\
\hline Photosensitivity & $53(52.5)$ & LDL & $118.3 \pm 47.3$ \\
\hline Oral Ulcers & $63(62.4)$ & Consumed C3 & $34(33.7)$ \\
\hline Arthritis & $50(49.5)$ & Consumed C4 & $20(19.8)$ \\
\hline Serositis & $39(38.6)$ & Treatment & $\underline{N}(\%)$. \\
\hline Renal disorders & $62(61.4)$ & HCQ & $89(94.6)$ \\
\hline Neuropsychiatric disorders & $13(14.9)$ & Endoxan & $62(65.9)$ \\
\hline PanCytopenia & $19(18.8)$ & Imuran & $67(71.2)$ \\
\hline Anti-nuclear Ab & $71(70.3)$ & Biological & $6(6.3)$ \\
\hline Anti-dsDNA Ab & $71(70.3)$ & & \\
\hline Other clinical manifestations & №(\%). & & \\
\hline Constitutional symptoms & $81(80.2)$ & & \\
\hline Mucocutaneous manifestation & $84(83.2)$ & & \\
\hline Vasculities & $28(28.7)$ & & \\
\hline Raynauds phenomena & $19(18.8)$ & & \\
\hline Alopecia & $30(29.7)$ & & \\
\hline Hypertension & $29(28.7)$ & & \\
\hline Thrombocytopenia & $29(28.7)$ & & \\
\hline Haemolyticanaemia & $16(15.8)$ & & \\
\hline Leucopenia & $34(33.7)$ & & \\
\hline Neutropenia & $13(12.9)$ & & \\
\hline Lymphopenia & $31(30.7)$ & & \\
\hline
\end{tabular}

Table (3). ROC curve results of selected microRNAs in SLE 


\begin{tabular}{|lllllll|}
\hline Parameters & Cut-off & AUC & Sensitivity (\%) & Specificity (\%) & $95 \%$ Cl & P-value \\
\hline miR_21 & 1.345 & 0.628 & 78 & 48 & $0.724-0.532$ & $P<0.01$ \\
\hline miR_24 & 0.115 & 0.374 & 70 & 42 & $0.473-0.274$ & $P<0.001$ \\
\hline miR_125 & 5.065 & 0.502 & 80 & 86 & $0.604-0.399$ & $P<0.001$ \\
\hline miR_146 & 1.185 & 0.610 & 65 & 60 & $0.712-0.509$ & $P<0.001$ \\
\hline miR_148 & 1.065 & 0.806 & 88 & 70 & $0.884-0.728$ & $P<0.001$ \\
\hline miR_155 & 0.815 & 0.764 & 81 & 64 & $0.848-0.581$ & $P<0.001$ \\
\hline
\end{tabular}

(AUC): Area under the curve, (CI): Confidence interval

Table (4). miRNA expression in SLE patients with different clinical manifestations 


\begin{tabular}{|c|c|c|c|c|c|c|c|}
\hline Clinical parameter & & $\begin{array}{l}\text { miR_21 } \\
\text { (Mean } \pm \\
\text { SE) }\end{array}$ & $\begin{array}{l}\text { miR_24 } \\
(\text { Mean } \pm S E)\end{array}$ & $\begin{array}{l}\text { miR_125 } \\
\text { (Mean } \pm \\
\text { SE) }\end{array}$ & $\begin{array}{l}\text { miR_146 } \\
\text { (Mean } \pm \\
\text { SE) }\end{array}$ & $\begin{array}{l}\text { miR_148 } \\
(\text { Mean } \pm S E)\end{array}$ & $\begin{array}{l}\text { miR_155 } \\
\text { (Mean } \pm \\
\text { SE) }\end{array}$ \\
\hline \multicolumn{8}{|l|}{ ACR criteria of SLE } \\
\hline \multirow[t]{2}{*}{ Malar rash } & No & $0.30 \pm 0.05$ & $2.17 \pm 0.43$ & $1.74 \pm 0.21$ & $3.05 \pm 0.63$ & $3.10 \pm 0.81$ & $3.82 \pm 0.57$ \\
\hline & Yes & $0.32 \pm 0.04$ & $2.15 \pm 0.23$ & $1.99 \pm 0.23$ & $3.15 \pm 0.34$ & $3.11 \pm 0.51$ & $4.37 \pm 0.65$ \\
\hline \multirow[t]{2}{*}{ Photosensitivity } & No & $0.28 \pm 0.047$ & $2.02 \pm 0.32$ & $1.82 \pm 0.25$ & $2.69 \pm 0.43$ & $3.63 \pm 0.74$ & $3.55 \pm 0.64$ \\
\hline & Yes & $0.34 \pm 0.05$ & $2.27 \pm 0.27$ & $2.01 \pm 0.25$ & $3.49 \pm 0.42^{\star}$ & $2.67 \pm 0.48$ & $4.75 \pm 0.69$ \\
\hline \multirow[t]{2}{*}{ Oral Ulcers } & No & $0.34 \pm 0.06$ & $2.03 \pm 0.28$ & $1.99 \pm 0.25$ & $2.81 \pm 0.48$ & $2.79 \pm 0.61$ & $3.79 \pm 0.58$ \\
\hline & Yes & $0.29 \pm 0.05$ & $2.27 \pm 0.30$ & $1.91 \pm 0.25$ & $3.39 \pm 0.40$ & $3.36 \pm 0.60$ & $4.54 \pm 0.71$ \\
\hline \multirow[t]{2}{*}{ Arthritis } & No & $0.29 \pm 0.44$ & $2.29 \pm 0.34$ & $1.89 \pm 0.24$ & $2.62 \pm 0.31$ & $3.22 \pm 0.61$ & $3.93 \pm 0.67$ \\
\hline & Yes & $0.31 \pm 0.06$ & $2.02 \pm 0.24$ & $1.95 \pm 0.27$ & $3.70 \pm 0.51$ & $3.09 \pm 0.64$ & $4.48 \pm 0.72$ \\
\hline \multirow[t]{2}{*}{ Serositis } & No & $0.34 \pm 0.05$ & $1.92 \pm 0.16$ & $1.91 \pm 0.23$ & $2.91 \pm 0.37$ & $2.42 \pm 0.43$ & $4.11 \pm 0.52$ \\
\hline & Yes & $0.27 \pm 0.05$ & 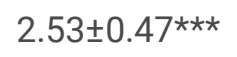 & $1.96 \pm 0.29$ & $3.47 \pm 0.53$ & $4.26 \pm 0.85^{\star \star \star}$ & $4.37 \pm 0.95$ \\
\hline \multirow[t]{2}{*}{ Renal disorders } & No & $0.21 \pm 0.03$ & $1.70 \pm 0.21$ & $1.80 \pm 0.29$ & $3.25 \pm 0.56$ & $2.37 \pm 0.37$ & $4.04 \pm 0.78$ \\
\hline & Yes & $0.36 \pm 0.05^{\star \star}$ & $2.41 \pm 0.31 *$ & $1.98 \pm 0.23$ & $3.09 \pm 0.36$ & $3.63 \pm 0.67^{\star \star}$ & $4.28 \pm 0.63$ \\
\hline \multirow{2}{*}{$\begin{array}{l}\text { Neuropsychiatric } \\
\text { disorders }\end{array}$} & No & $0.31 \pm 0.04$ & $2.22 \pm 0.23$ & $1.81 \pm 0.19$ & $3.07 \pm 0.30$ & $3.12 \pm 0.49$ & $3.94 \pm 0.49$ \\
\hline & Yes & $0.32 \pm 0.06$ & $1.82 \pm 0.43$ & $2.46 \pm 0.49$ & $3.35 \pm 0.99$ & $3.04 \pm 0.70$ & $5.50 \pm 1.47$ \\
\hline \multirow[t]{2}{*}{ PanCytopenia } & No & $0.31 \pm 0.04$ & $2.27 \pm 0.26$ & $1.83 \pm 0.19$ & $3.29 \pm 0.39$ & $3.11 \pm 0.48$ & $3.95 \pm 0.51$ \\
\hline & Yes & $0.33 \pm 0.09$ & $1.78 \pm 0.25$ & $2.21 \pm 0.42$ & $2.63 \pm 0.38$ & $3.09 \pm 0.96$ & $5.01 \pm 1.19$ \\
\hline \multicolumn{8}{|c|}{ Other clinical Manifestations } \\
\hline \multirow{2}{*}{$\begin{array}{l}\text { Constitutional } \\
\text { symptoms }\end{array}$} & No & $0.37 \pm 0.06$ & $1.88 \pm 0.35$ & $1.91 \pm 0.34$ & $2.43 \pm 0.32$ & $3.13 \pm 1.07$ & $3.73 \pm 0.69$ \\
\hline & Yes & $0.29 \pm 0.04$ & $2.24 \pm 0.24$ & $1.93 \pm 0.21$ & $3.34 \pm 0.38$ & $3.10 \pm 0.46$ & $4.35 \pm 0.59$ \\
\hline \multirow{2}{*}{$\begin{array}{l}\text { Mucocutaneous } \\
\text { manifestation }\end{array}$} & No & $0.34 \pm 0.08$ & $2.44 \pm 0.73$ & $1.91 \pm 0.37$ & $3.16 \pm 1.10$ & $3.93 \pm 1.34$ & $3.20 \pm 0.75$ \\
\hline & Yes & $0.31 \pm 0.04$ & $2.09 \pm 0.19$ & $1.93 \pm 0.20$ & $3.11 \pm 0.29$ & $2.94 \pm 0.44$ & $4.42 \pm 0.55$ \\
\hline \multirow[t]{2}{*}{ Vasculities } & No & $0.32 \pm 0.05$ & $2.07 \pm 0.24$ & $1.71 \pm 0.18$ & $3.26 \pm 0.34$ & $2.50 \pm 0.31$ & $3.80 \pm 0.51$ \\
\hline & Yes & $0.31 \pm 0.06$ & $2.37 \pm 0.41$ & $2.44 \pm 0.42^{\star \star}$ & $2.81 \pm 0.63$ & $4.56 \pm 1.21^{\star \star \star}$ & $5.18 \pm 1.07$ \\
\hline \multirow{2}{*}{$\begin{array}{l}\text { Raynauds } \\
\text { phenomena }\end{array}$} & No & $0.34 \pm 0.04$ & $2.19 \pm 0.24$ & $1.90 \pm 0.21$ & $3.27 \pm 0.37$ & $3.01 \pm 0.45$ & $4.07 \pm 0.48$ \\
\hline & Yes & $0.18 \pm 0.03^{*}$ & $2.03 \pm 0.37$ & $2.02 \pm 0.33$ & $2.50 \pm 0.26$ & $3.55 \pm 1.21$ & $4.80 \pm 1.53$ \\
\hline \multirow[t]{2}{*}{ Alopecia } & No & $0.32 \pm 0.05$ & $2.24 \pm 0.27$ & $2.06 \pm 0.25$ & $3.18 \pm 0.42$ & $3.57 \pm 0.61$ & $4.31 \pm 0.68$ \\
\hline & Yes & $0.31 \pm 0.06$ & $2.05 \pm 0.31$ & $1.73 \pm 0.22$ & $3.09 \pm 0.39$ & $2.27 \pm 0.43$ & $4.09 \pm 0.55$ \\
\hline \multirow[t]{2}{*}{ Hypertension } & No & $0.28 \pm 0.04$ & $2.16 \pm 0.23$ & $1.96 \pm 0.22$ & $2.95 \pm 0.34$ & $3.06 \pm 0.52$ & $3.94 \pm 0.48$ \\
\hline & Yes & $0.39 \pm 0.09$ & $2.15 \pm 0.44$ & $1.84 \pm 0.31$ & $3.57 \pm 0.67$ & $3.22 \pm 0.78$ & $4.91 \pm 1.18$ \\
\hline \multirow[t]{2}{*}{ Thrombocytopenia } & No & $0.29 \pm 0.04$ & $2.19 \pm 0.04$ & $1.81 \pm 0.22$ & $3.25 \pm 0.41$ & $3.23 \pm 0.54$ & $4.37 \pm 0.67$ \\
\hline & Yes & $0.34 \pm 0.08$ & $2.07 \pm 0.25$ & $2.13 \pm 0.30$ & $2.88 \pm 0.42$ & $2.88 \pm 0.71$ & $3.91 \pm 0.57$ \\
\hline
\end{tabular}




\begin{tabular}{|lccccccc|} 
Haemolyticanaemia & No & $0.33 \pm 0.04$ & $2.29 \pm 0.24$ & $1.87 \pm 0.18$ & $3.17 \pm 0.38$ & $3.18 \pm 0.52$ & $3.94 \pm 0.47$ \\
& Yes & $0.26 \pm 0.06$ & $1.61 \pm 0.21$ & $2.16 \pm 0.52$ & $2.96 \pm 0.34$ & $2.82 \pm 0.55$ & $5.27 \pm 1.49$ \\
\hline Leucopenia & No & $0.29 \pm 0.04$ & $2.20 \pm 0.29$ & $1.75 \pm 0.20$ & $3.12 \pm 0.38$ & $2.53 \pm 0.34$ & $3.79 \pm 0.60$ \\
& Yes & $1.12 \pm 0.15$ & $2.08 \pm 0.29$ & $2.18 \pm 0.33$ & $3.28 \pm 0.52$ & $4.06 \pm 0.94 * \star$ & $4.81 \pm 0.83$ \\
\hline Neutropenia & No & $0.29 \pm 0.04$ & $2.10 \pm 0.22$ & $1.81 \pm 0.21$ & $3.06 \pm 0.29$ & $2.56 \pm 0.38$ & $3.76 \pm 0.46$ \\
& Yes & $0.37 \pm 0.05^{\star}$ & $2.28 \pm 0.60$ & $2.39 \pm 0.31$ & $3.59 \pm 1.09 *$ & $5.82 \pm 1.48 * \star$ & $6.17 \pm 1.69 *$ \\
\hline Lymphopenia & No & $0.27 \pm 0.04$ & $2.22 \pm 0.29$ & $1.75 \pm 0.20$ & $2.74 \pm 0.23$ & $2.59 \pm 0.33$ & $3.73 \pm 0.60$ \\
& Yes & $0.36 \pm 0.06$ & $2.05 \pm 0.31$ & $2.18 \pm 0.35$ & $3.79 \pm 0.67 *$ & $4.11 \pm 0.97 * \star$ & $4.93 \pm 0.85$ \\
\hline
\end{tabular}

$\mathrm{P}<0.05(*), P<0.02(* *) ; P<0.001(*)$

Table (5). miRNA expression in SLE patients with different treatments

\begin{tabular}{|c|c|c|c|c|c|c|c|}
\hline \multicolumn{2}{|c|}{ Clinical parameter } & \multirow{2}{*}{$\begin{array}{l}\text { miR 21 } \\
(\text { Mean } \pm \text { SE) }\end{array}$} & \multirow{2}{*}{$\begin{array}{l}\text { miR_24 } \\
\text { (Mean } \pm \text { SE) }\end{array}$} & \multirow{2}{*}{$\begin{array}{l}\text { miR_125 } \\
\text { (Mean } \pm \text { SE) }\end{array}$} & \multirow{2}{*}{$\begin{array}{l}\text { miR_146 } \\
\text { (Mean } \pm \text { SE) }\end{array}$} & \multirow{2}{*}{$\begin{array}{l}\text { miR_148 } \\
(\text { Mean } \pm \text { SE) }\end{array}$} & \multirow{2}{*}{$\begin{array}{l}\text { miR_155 } \\
(\text { Mean } \pm \text { SE) }\end{array}$} \\
\hline \multicolumn{2}{|l|}{ Treatment } & & & & & & \\
\hline \multirow[t]{2}{*}{$\mathrm{HCQ}$} & No & $0.23 \pm 0.06$ & $1.97 \pm 0.56$ & $1.97 \pm 0.41$ & $3.08 \pm 0.94$ & $3.12 \pm 1.02$ & $2.47 \pm 0.62$ \\
\hline & Yes & $0.31 \pm 0.04$ & $2.16 \pm 0.22$ & $1.89 \pm 0.19$ & $3.17 \pm 0.33$ & $3.14 \pm 0.47$ & $4.42 \pm 0.54$ \\
\hline \multirow[t]{2}{*}{ Endoxan } & No & $0.18 \pm 0.02$ & $1.99 \pm 0.28$ & $2.23 \pm 0.44$ & $2.52 \pm 0.29$ & $2.97 \pm 0.84$ & $4.09 \pm 0.67$ \\
\hline & Yes & $0.37 \pm 0.05^{\star \star}$ & $2.21 \pm 0.28$ & $1.74 \pm 0.15^{\star \star \star}$ & $3.49 \pm 0.43$ & $3.22 \pm 0.49$ & $4.23 \pm 0.65$ \\
\hline \multirow[t]{2}{*}{ Imuran } & No & $0.18 \pm 0.03$ & $2.29 \pm 0.53$ & $1.87 \pm 0.43$ & $3.49 \pm 0.86$ & $3.58 \pm 0.98$ & $4.11 \pm 1.09$ \\
\hline & Yes & $0.35 \pm 0.05^{\star \star}$ & $2.08 \pm 0.21$ & $1.92 \pm 0.19$ & $3.05 \pm 0.29 * *$ & $2.97 \pm 0.47$ & $4.21 \pm 0.53$ \\
\hline \multirow[t]{2}{*}{ Corticosteroids } & No & $0.32 \pm 0.03$ & $1.04 \pm 0.11$ & $1.05 \pm 0.15$ & $1.80 \pm 0.21$ & $6.21 \pm 0.22$ & $3.17 \pm 0.45$ \\
\hline & Yes & $0.30 \pm 0.04$ & $2.15 \pm 0.21$ & $1.91 \pm 0.18$ & $3.18 \pm 0.31$ & $3.09 \pm 0.44$ & $4.19 \pm 0.49$ \\
\hline \multirow[t]{2}{*}{ Biologic } & No & $0.27 \pm 0.03$ & $2.19 \pm 0.23$ & $1.92 \pm 0.19$ & $3.06 \pm 0.33$ & $3.26 \pm 0.49$ & $4.19 \pm 0.53$ \\
\hline & Yes & $0.49 \pm 0.24^{\star \star}$ & $0.81 \pm 0.23$ & $1.62 \pm 0.37$ & $1.80 \pm 0.53$ & $2.30 \pm 0.39$ & $1.30 \pm 0.08^{*}$ \\
\hline
\end{tabular}

$\mathrm{P}<0.05(*), P<0.02(* *) ; P<0.001(*)$

Table (6). Percentage of Treg cells in SLE patients with different clinical manifestations and different treatments 


\begin{tabular}{|c|c|c|c|c|c|}
\hline Demographic data & & Mean \pm SD & & & Mean \pm SD \\
\hline ACR criteria of SLE & - & - & Treatment & & - \\
\hline \multirow[t]{2}{*}{ Malar rash } & NO & $6.03 \pm 0.89$ & HCQ & NO & $7.91 \pm 4.28$ \\
\hline & Yes & $6.99 \pm 1.21$ & & Yes & $6.85 \pm 1.16$ \\
\hline \multirow[t]{2}{*}{ Photosensitivity } & NO & $3.75 \pm 0.98$ & Endoxan & NO & $6.16 \pm 2.11$ \\
\hline & Yes & $8.04 \pm 1.38^{\star \star}$ & & Yes & $7.51 \pm 1.32$ \\
\hline \multirow[t]{2}{*}{ Oral Ulcers } & NO & $6.71 \pm 2.29$ & Imuran & NO & $8.60 \pm 1.34$ \\
\hline & Yes & $6.98 \pm 1.26$ & & Yes & $6.49 \pm 1.42$ \\
\hline \multirow[t]{2}{*}{ Arthritis } & NO & $7.40 \pm 1.52$ & Corticosteroids & NO & $6.55 \pm 1.09$ \\
\hline & Yes & $6.43 \pm 1.72$ & & Yes & $6.99 \pm 1.13$ \\
\hline \multirow[t]{2}{*}{ Serositis } & NO & $6.95 \pm 1.28$ & Biologic & NO & $6.74 \pm 1.10$ \\
\hline & Yes & $6.80 \pm 2.08$ & & Yes & $6.71 \pm 1.09$ \\
\hline \multirow[t]{2}{*}{ Renal disorders } & NO & $6.06 \pm 1.67$ & - & - & - \\
\hline & Yes & $7.42 \pm 1.47$ & & & \\
\hline \multirow[t]{2}{*}{ Neuropsychiatric disorders } & NO & $6.89 \pm 1.09$ & & & \\
\hline & Yes & $5.08 \pm 1.02$ & & & \\
\hline \multirow[t]{2}{*}{ PanCytopenia } & NO & $6.91 \pm 1.33$ & & & \\
\hline & Yes & $3.61 \pm 1.47$ & & & \\
\hline Other clinical manifestations & & - & & & \\
\hline \multirow[t]{2}{*}{ Constitutional symptoms } & NO & $5.25 \pm 0.21$ & & & \\
\hline & Yes & $7.08 \pm 1.21$ & & & \\
\hline \multirow[t]{2}{*}{ Mucocutaneous manifestation } & NO & $6.30 \pm 1.47$ & & & \\
\hline & Yes & $6.94 \pm 1.17$ & & & \\
\hline \multirow[t]{2}{*}{ Vasculities } & NO & $6.49 \pm 1.05$ & & & \\
\hline & Yes & $10.49 \pm 6.09$ & & & \\
\hline \multirow[t]{2}{*}{ Raynauds phenomena } & NO & $6.35 \pm 0.98$ & & & \\
\hline & Yes & $22.66 \pm 0.92^{\star \star *}$ & & & \\
\hline \multirow[t]{2}{*}{ Alopecia } & NO & $6.77 \pm 1.28$ & & & \\
\hline & Yes & $7.21 \pm 2.19$ & & & \\
\hline \multirow[t]{2}{*}{ Hypertension } & NO & $6.87 \pm 1.14$ & & & \\
\hline & Yes & $6.95 \pm 2.45$ & & & \\
\hline \multirow[t]{2}{*}{ Thrombocytopenia } & NO & $7.44 \pm 1.73$ & & & \\
\hline & Yes & $6.28 \pm 1.31$ & & & \\
\hline \multirow[t]{2}{*}{ Haemolyticanaemia } & NO & $6.87 \pm 1.28$ & & & \\
\hline & Yes & $7.05 \pm 1.67$ & & & \\
\hline
\end{tabular}

Page 18/23 


\begin{tabular}{|lll|}
\hline Leucopenia & NO & $7.16 \pm 1.57$ \\
Yes & $6.63 \pm 1.16$ \\
\hline Neutropenia & NO & $6.87 \pm 1.16$ \\
& Yes & $10.63 \pm 1.12$ \\
\hline Lymphopenia & NO & $7.16 \pm 1.57$ \\
& Yes & $6.63 \pm 1.16$ \\
\hline
\end{tabular}

$\mathrm{P}<0.01(* *), \mathrm{P}<0.001$ (***)

\section{Figures}
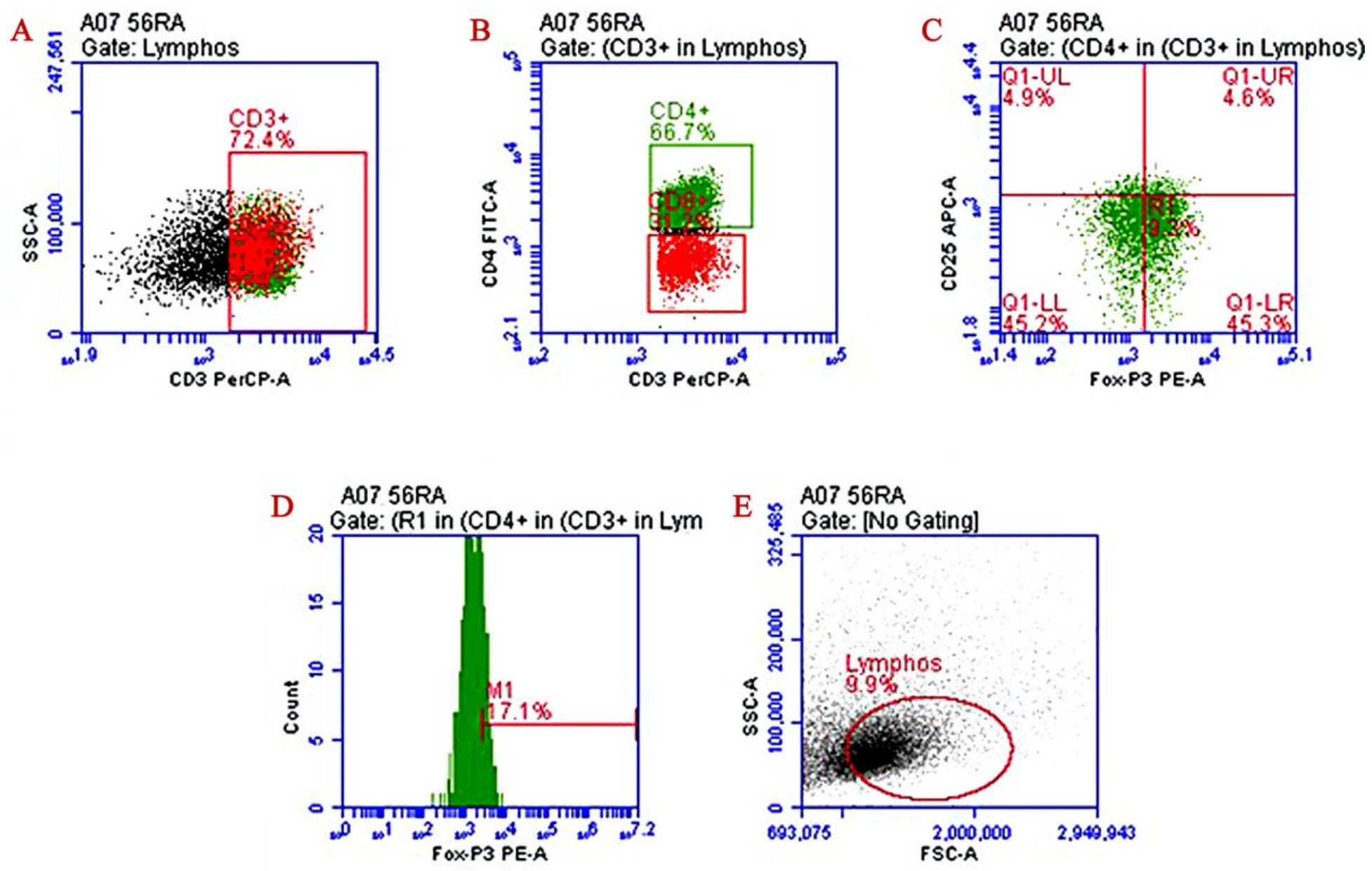

Figure 1

Flow cytometric detection of Treg cells 


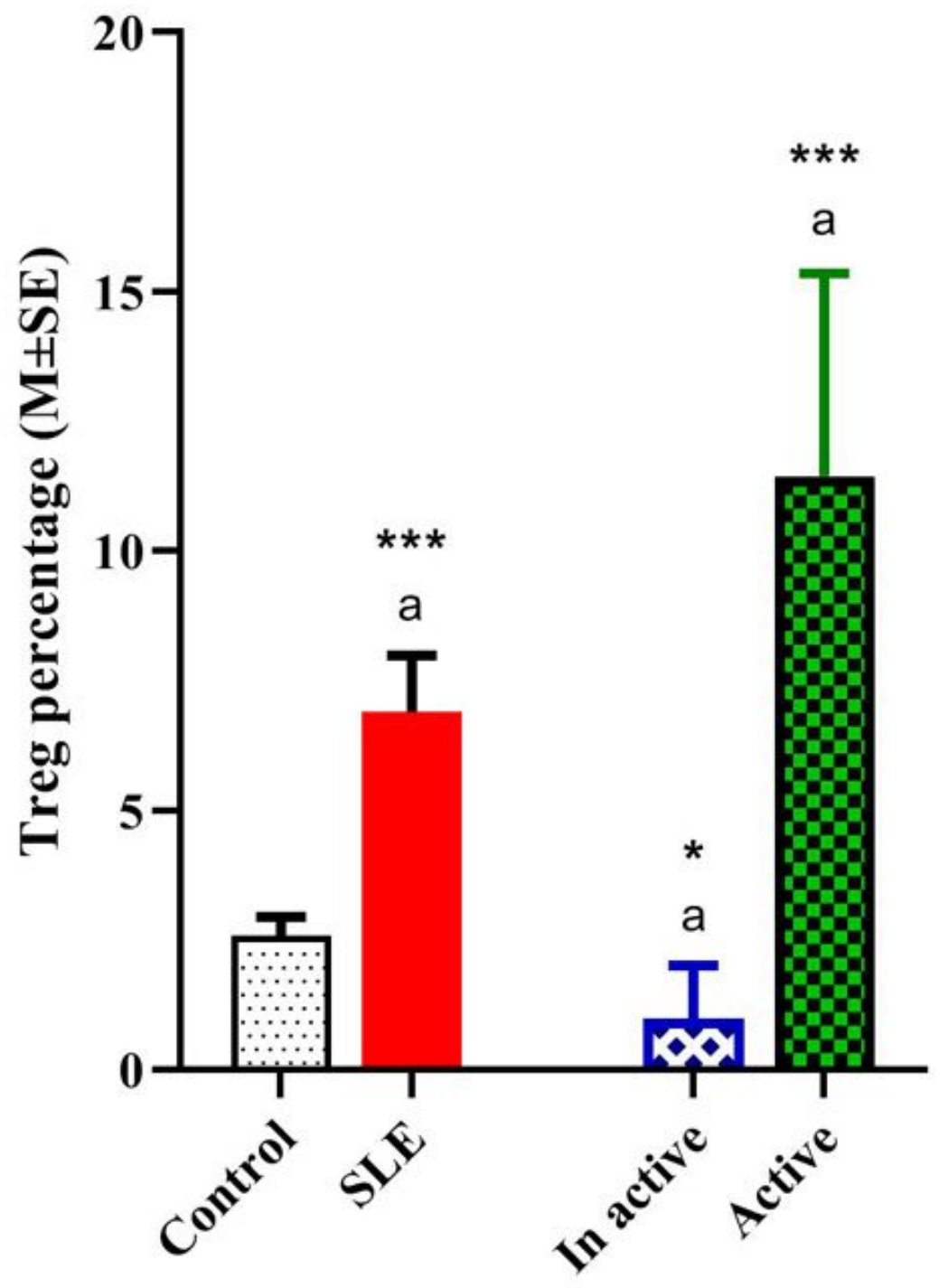

Figure 2

Percentages of Treg in controls and SLE patients (active and inactive patients). $p<0.05\left({ }^{*}\right), p<0.02(* \star) ; p<0.001(* \star *)$ 
A

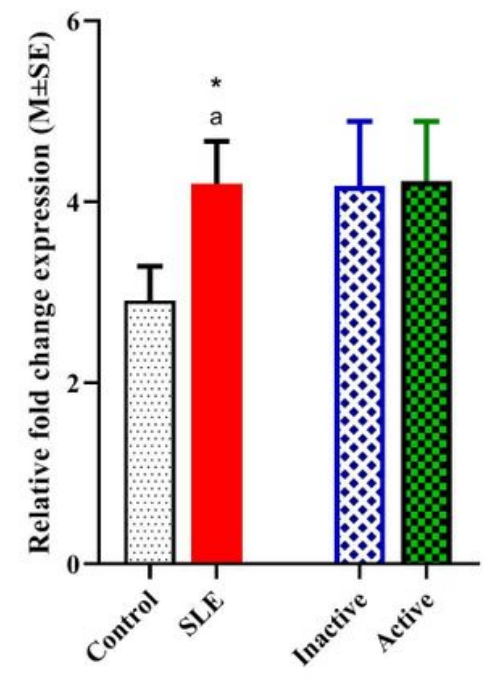

D

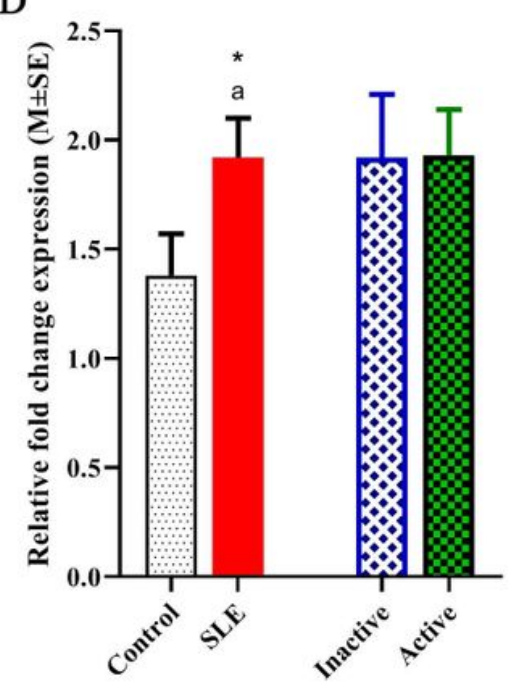

B

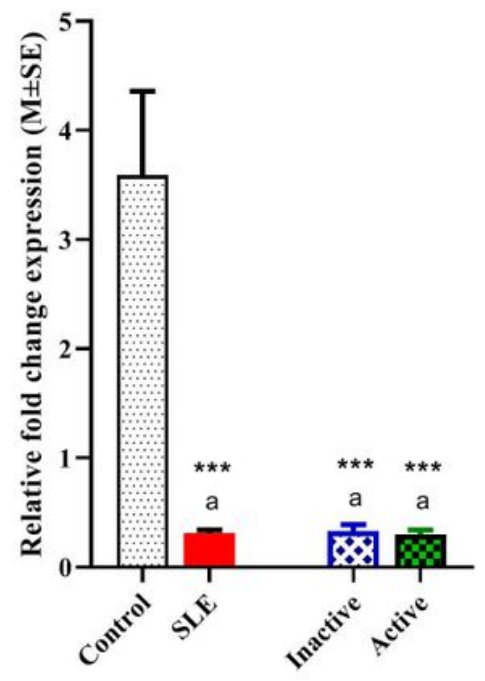

E

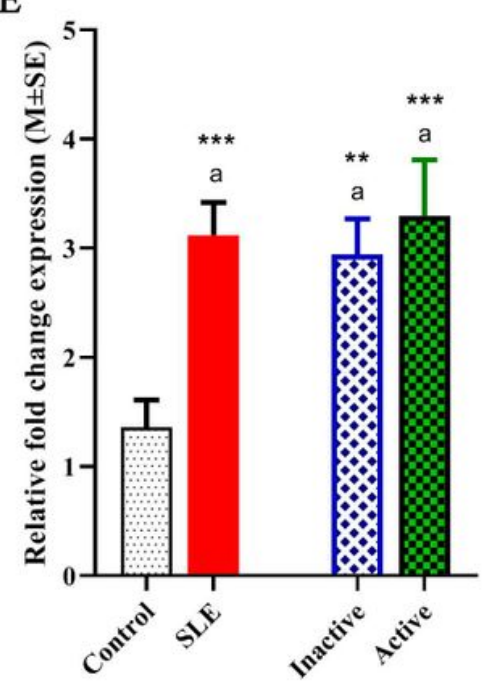

C

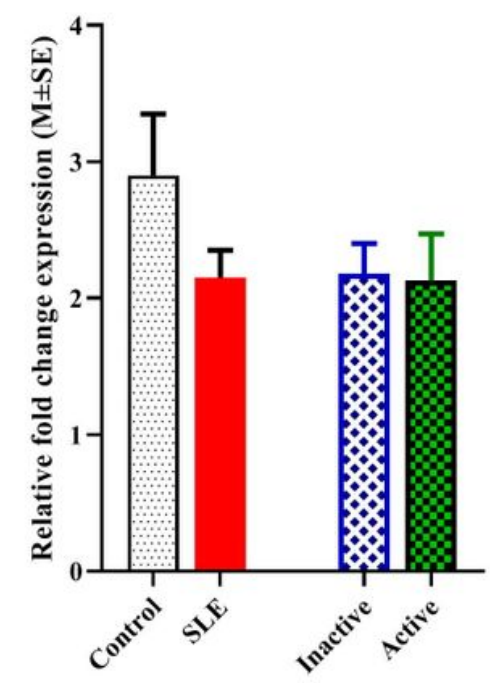

F

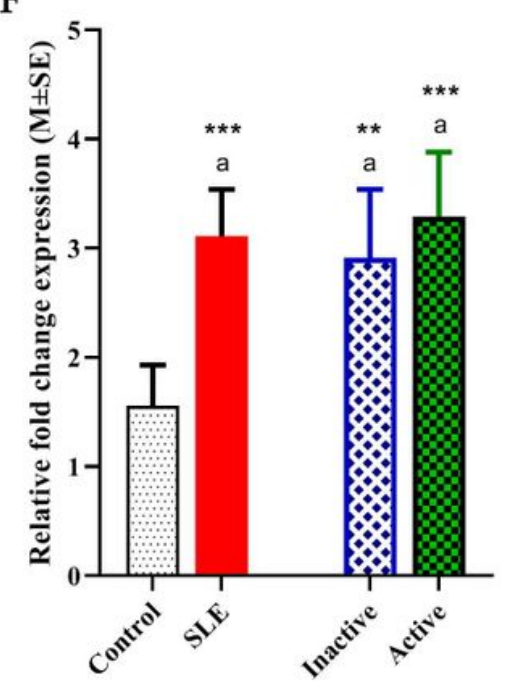

Figure 3

The relative fold change expression level of miRNAs in controls and SLE patients (active and inactive patients). $p<0.05\left({ }^{*}\right)$, $p<0.02(* *) ; p<0.001(* \star *)$ 
A

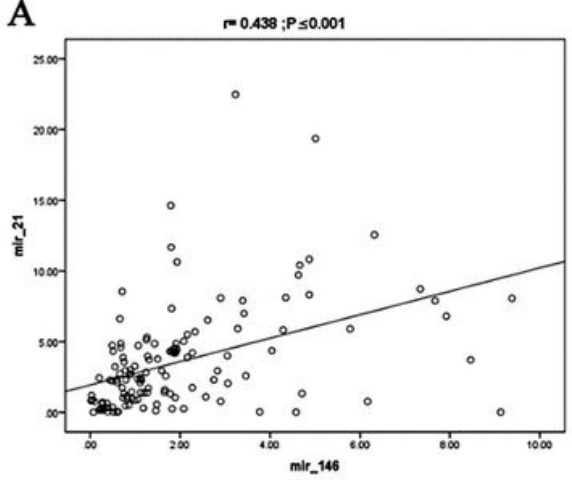

D

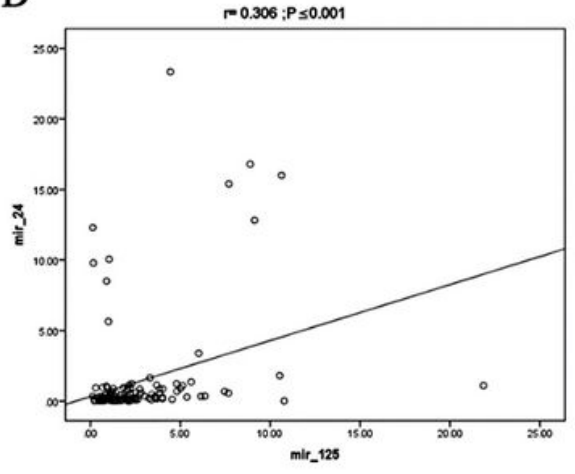

B

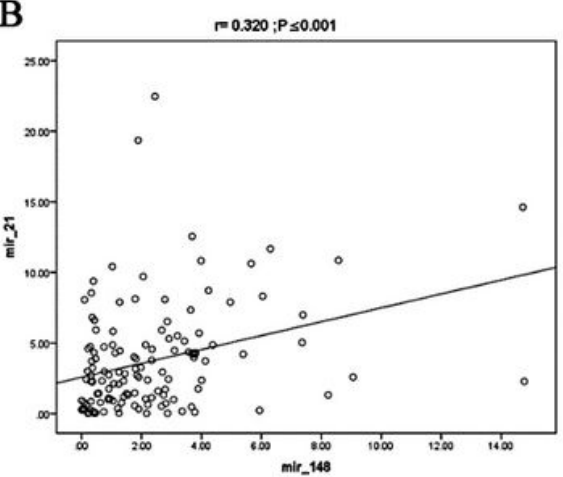

E

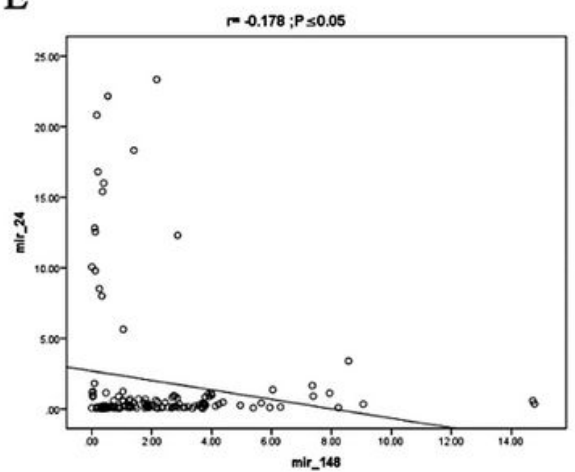

C

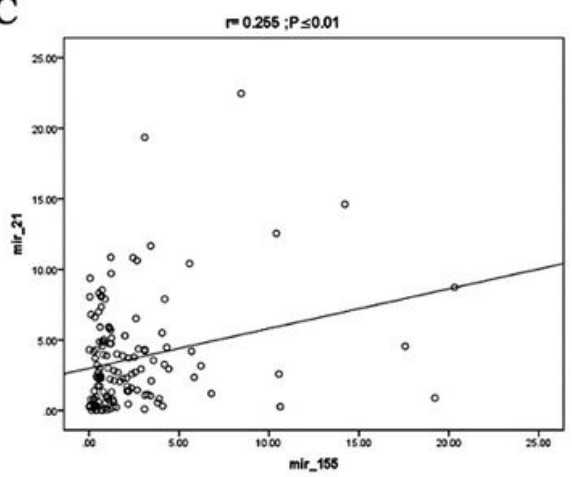

F

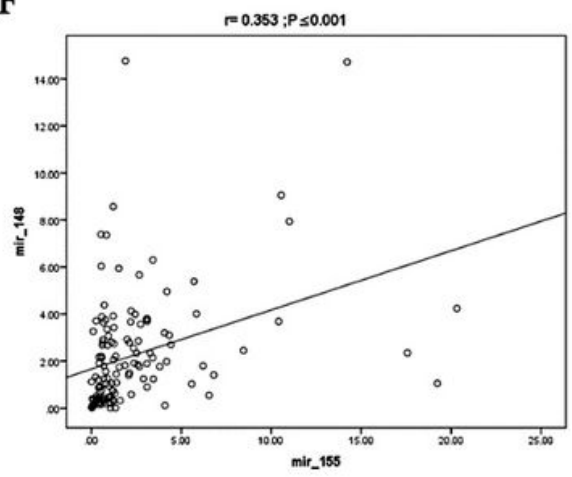

Figure 4

Correlation between miRNAs in SLE patients 
A

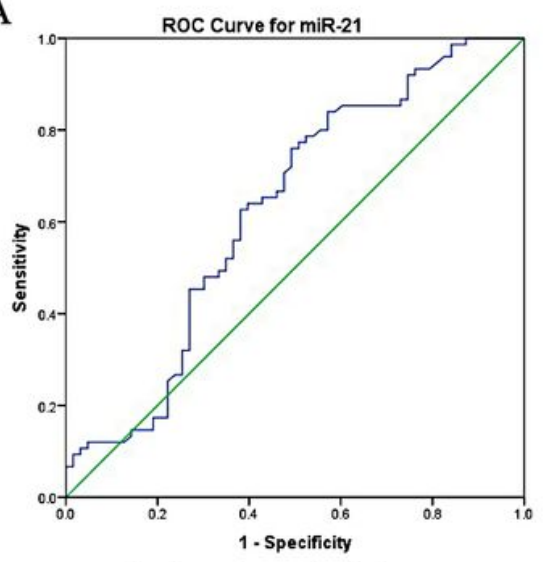

Diagonal segments are produced by ties.

D

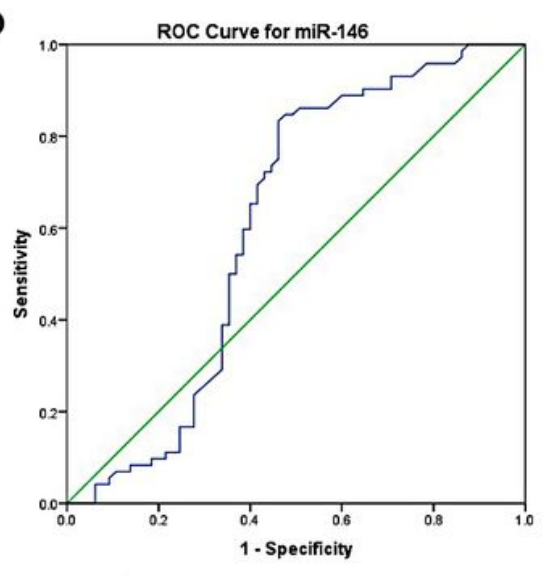

Diagonal segments are produced by ties.
B

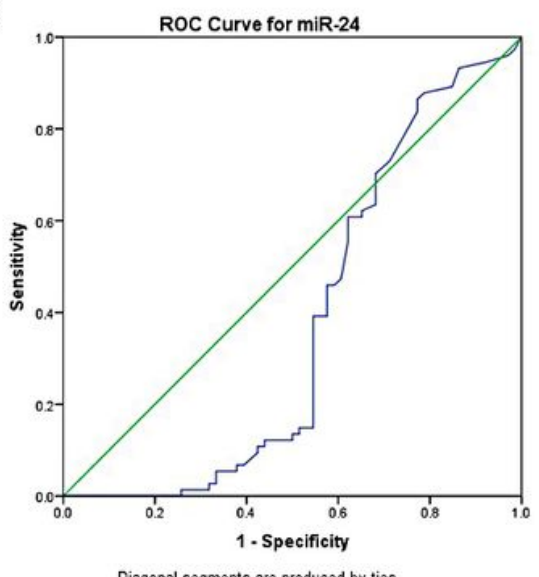

Diagonal segments are produced by ties.

$\mathrm{E}$

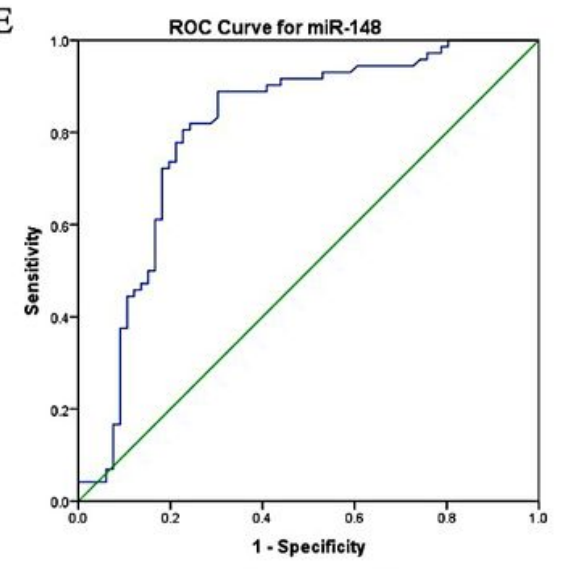

Diagonal segments are produced by ties.
C

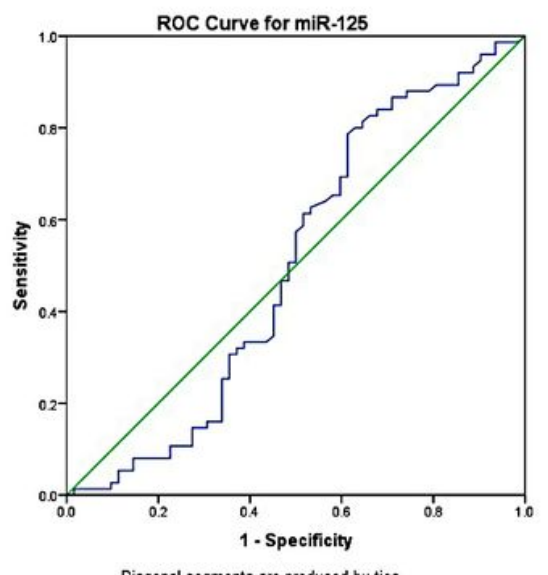

Diagonal segments are produced by ties.

F

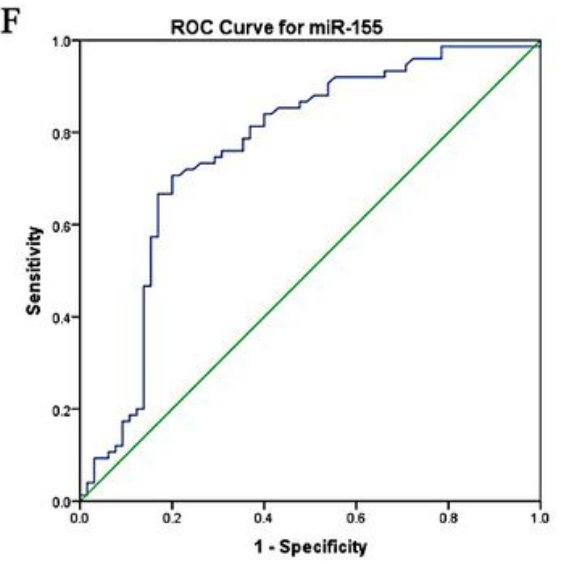

Diagonal segments are produced by ties.

\section{Figure 5}

The Roc curve of miRNAs in SLE patients 